\title{
The impact of digitalization on the demand for labor in the context of working specialties: Spatial analysis*
}

\author{
J. V.Dubrovskaya, E. V.Kozonogova \\ Perm National Research Polytechnic University, \\ 29, Komsomolsky pr., Perm, 614000, Russian Federation
}

For citation: Dubrovskaya J. V., Kozonogova E. V. (2021) The impact of digitalization on the demand for labor in the context of working specialties: Spatial analysis. St Petersburg University Journal of Economic Studies, vol.37, iss. 3, pp. 395-412. https://doi.org/10.21638/spbu05.2021.302

The spread of digital technologies, as well as the expansion of remote work practices, have a direct impact on the transformation of the labor market. At the same time, there is no wellestablished scholarly consensus about the nature and consequences of this influence. The key premise of the article is that there are relatively few empirical studies on the labor market that account for the influence of the location of regions relative to each other. This article tests a hypothesis about the significance of location and neighborhood of territories on labor demand in the context of economic digitalization, based on the calculation of coefficients of demand localization for specialists of different profiles and methods of spatial econometrics. The assessment is based on the evaluation of the registered unemployment rate heterogeneity for municipalities in the Perm region of the Russian Federation, using the global and local Moran's indexes. The studies revealed a positive spatial autocorrelation among neighboring municipalities that proved the high spatial heterogeneity of the registered unemployment rate. Centers of localization and development of labor resources ("growth poles") and territories affected by spillover effects were also identified. This demonstrates that spatial inter-territorial relations have a significant impact on the demand for labor, which makes it necessary to account for spatial effects when modeling dynamics of employment indicators. The method of labor market analysis based on the assessment of spatial heterogeneity of the unemployment rate and the calculation of localization coefficients is universal and can be applied to various taxonomic units.

Keywords: demand for labor, registered unemployment rate, Moran index, localization rates, digital economy, spatial heterogeneity.

\section{Introduction}

The introduction of information technology in economic sectors and social life contributes to the transformation of entire industries, complexes, and markets. Therefore, the question of how the consequences of digitalization will appear in the future becomes more and more relevant. How strong will they be for states, for companies, and individuals? At the same time, special attention should be paid to the impact of digitalization on the labor market and the educational system.

* The study was carried out with the financial support of the Russian Foundation for Basic Research within the framework of scientific project no 19-010-00562.

(C) St. Petersburg State University, 2021 
According to article 5 of the law of the Russian Federation "On employment of the population in the Russian Federation"1, the state policy in the field of promoting employment in Russia is aimed at developing labor resources and increasing their mobility. Wherein, the most important direction of increasing labor productivity is the development and implementation of technological innovations in production processes through the integration of digital solutions. Digital transformation of enterprises is becoming a key factor in the competitiveness of both separate territories and countries as a whole. Thus, in a study on the relationship between digitalization and business success [Calvino, Criscuolo, 2019], an important empirical finding is that technology-based driving forces explain about $40 \%$ of the observed business dynamics.

A review of papers on unemployment research has confirmed the scholarly interest in assessing the impact of digitalization on unemployment. For instance, W. Huws, referring to the term "digital labor," examined important trends in the transformation of the labor market under the influence of digitalization [Huws, 2014]. I. S. Lola and M.B.Bakeev established the importance and significance of criteria for digital transformations and the digitalization of labor in manufacturing [Lola, Bakeev, 2019]. S.D. Bodrunov, D.S. Demidenko and V.A.Plotnikov proved the complementarity of the trends of reindustrialization and the development of the digital economy [Bodrunov, Demidenko, Plotnikov, 2018].

Speaking about the impact of digitalization on demand for labor, it is important to note that research is based on the well-known theory of technological unemployment. As J.M. Keynes noted "The increase of technical efficiency has been taking place faster than we can deal with the problem of labor ab-sorption" [Keynes, 1931]. Despite the fact that most modern scholars consider digitalization to be a factor in increasing technical unemployment [Brynjolfsson, McAfee, 2014; Frey, Osborne, 2013] ${ }^{2}$, we found a number of works confirming the opposite. M. Annunziata and S. Biller note, "The shifting of tasks from humans to machines has gradually unburdened us of a number of physically arduous or mind-numbingly repetitive tasks... Technological progress will push a growing share of the workforce toward creativity and entrepreneurship, where humans have a clear comparative advantage over machines" [Annunziata, Biller, 2014, p. 13]. S. Pfeiffer and A. Suphan follow similar views about the demand for experience-based knowledge [Pfeiffer, Suphan, 2015]. The same is found in a study by the Boston Consulting Group: "In our analysis of Industry 4.0's impact on German manufacturing, we found that the growth it stimulates will lead to a $6 \%$ increase in employment during the next 10 years... And demand for employees in the mechanical engineering sector may rise even more by as much as $10 \%$ during the same period" [Rüßmann et al., 2015]. According this study, job growth in German manufacturing between 2015 and 2025 will amount numerically to about 390,000 jobs. Also, the positive impact of digitalization on the productivity and employment growth was proved by R. Evangelista, P. Guerrieri and V. Meliciani. Based on the analysis of the economic impact of digital technologies in Europe, the authors empirically proved that "the usage of ICT, and mostly digital empowerment, exert the major economic

${ }^{1}$ Law of the Russian Federation dated 19.04.1991 no. 1032-1 (amended on 08.12.2020) "On Employment of the Population in the Russian Federation". URL: http://www.consultant.ru/document/cons_ doc_LAW_60/ (accessed: 06.06.2020). (In Russian)

${ }^{2}$ Skills panorama. Skills obsolescence (\%) across countries in 2014. (2015) Skills panorama. URL: http://skillspanorama.cedefop.europa.eu/en/indicators/skills-obsolescence (accessed: 06.06.2020). 
effects, especially on employment also favoring the inclusion of 'disadvantaged' groups in the labor market" [Evangelista, Guerrieri, Meliciani, 2014, p. 2].

In fact, the debate about the impact of technological change on the quantity of employment, composition of skills change, and wage structure change has a long tradition in economics, and after two centuries it has not produced any conclusive answer [Pianta, 2005].

Despite the contradictory views on the prospects for changing the demand for labor under the influence of digitalization, scholars agree on the need to modernize and adapt the system of training and education. As is noted by M. Barzotto and L. De Propris [Barzotto, De Propris, 2018, p. 1053], the diffusion of new "smart" technologies is driving a disruptive re-composition of skills and competences. OECD warns that "rapid technological change could challenge the adequacy of [today] skills and training systems" leading to skills obsolescence ${ }^{3}$. A deep analysis of the impact of economic digitalization on the labor market and the system of training professional personnel was carried out by N. V. Kuznetsov [Kuznetsov, 2018]. Yu. E. Shatilo and E.S. Kopkova identified the most and least promising jobs in the near future [Shatilo, Kopkova, 2017]. G. Yu. Belyaev pointed out the negative trends in the development of modern education [Belyaev, 2017]. V. V. Ivanov, A. A. Kaybiyaynen and L. T. Miftakhutdinova in their study examined the problems of digitalization in terms of the pedagogical problem of training engineering personnel [Ivanov, Kaybiyaynen, Miftakhutdinova, 2017]. H. Hirsch-Kreinsen used the example of the progressive usage of digital technologies in German industry to show the importance of such processes as "upgrading" and "polarization" of skills [Hirsch-Kreinsen, 2016]. M. Barzotto and L. De Propris explore what skills mix might be able to deliver greater regional productivity [Barzotto, Propris, 2018, p. 1053]. We agree with R. Evangelista "that not only the use of digital technologies tends to substitute low-qualified labor routines but also that labor (or total factor) productivity gains can be obtained only if the adoption and use of ICT are complemented with qualified skills and competencies" [Evangelista, Guerrieri, Meliciani, 2014, p.9].

Thus, empirical research confirms that both positive and negative effects of digitalization on employment are unevenly distributed between different sectors of the economy. It is important to note that one of the problems in empirical research is the effects of the development of neighboring regional economies. Such factors as the mobility of capital and labor, the spread (diffusion) of knowledge and technology, and transportation costs significantly affect interregional interaction, and from there the main indicators of regions and their growth rates. Due to the openness of regional economies, econometric models should take into account their interaction and mutual influence. The basic premise of spatial econometrics is that the studied indicators can be autocorrelated in space, i. e. observations of the studied indicators in space and their dynamics are not random, but are determined by regional affiliation [Lugovoy et al., 2007]. It was theoretically proved that the estimates of the parameters of the regression models are biased and ineffective when the spatial effects are not taken into account in the models [Anselin, 2006; Elhorst, 2009; Lee, $\mathrm{Yu}, 2006]$.

${ }^{3}$ Enabling the Next Production Revolution: The Future of Manufacturing and Services - Interim report. (2016) OECD. URL: https://www.oecd.org/mcm/documents/Enabling-the-next-production-revolution-the-future-of-manufacturing-and-services-interim-report.pdf (accessed: 02.06.2020). 
Therefore, it is worth highlighting works devoted to the spatial aspects of consideration of the unemployment. E. Lopez-Bazo, T. Barrio and M. Artis proposed a set of tools for analysing the regional distribution of unemploymen in Spain. Applying the authors' spatial exploratory techniques and spatial econometric models complements the traditional regression analysis and provides new insights into the geographical distribution of unemployment [Lopez-Bazo, Barrio, Artis, 2002]. F. Lottmann analyzed determinants for regional differences in German unemployment rates [Lottmann, 2012]. O.A.Demidova revealed interregional differences in unemployment rates, relative wages and growth in GRP in Russia [Demidova, 2014]. V.A. Markov discovered the existence of a spatial interdependence between the geographical proximity of the regions and their similarity in terms of unemployment [Markov, 2015]. V. A. Rusanovsky and V. A. Markov explore the spatial distribution of the employed people and the economic potential of the territories [Rusanovsky, Markov, 2016; 2018]. They identified regions that act as centers of economic development, and regions that "draw back" labor from neighboring regions. Scientists have also proved the inverse relationship between the level of regional urbanization and unemployment.

In the course of the literature review, we did not identify a study of unemployment problems that considered digital and spatial aspects simultaneously. At the same time, an assessment of the dependence of the demand for labor on the digitalization of the Russian economy based on tools of spatial econometrics can give new, non-trivial results.

It is important to note that our previous work on labor market research [Kozonogova, Dubrovskaya, Tiunov, 2020; Tiunov, Dubrovskaya, 2019] empirically demonstrated that the level of digitalization has the greatest impact on labor productivity in comparison with other factors of labor market development (migration intensity, the population density, urbanization spread). The authors constructed an econometric model where, as a result indicator of a multifactor model of the labor market, an indicator of labor productivity in the regions of Russia was used. The following regional indicators were chosen as explanatory variables: digitalization index; share of urban population in the regions of the Russian Federation; population density; migration growth rate.

As a result of the of the obtained coefficient values interpretation in the regression model, a key conclusion was that increasing labor productivity based on universal digitalization in the long run will lead to an increase in technological unemployment. At the same time, an additional quantitative assessment of the significance of the spatial effects of the digitalization impact on labor demand in the context of specialties is required. The empirical verification of this hypothesis is the subject of the present study.

\section{Methods of research}

An analysis of demand in the regional labor market in the context of specific profiles of specialists was carried out on the example of data on municipalities. This decision is due to the features of the spatial econometrics tools used in the study. Sscholars studying spatial relationships in different countries have broadly substantiated the importance of using microeconomic data precisely [Diodato, Weterings, 2015; Martynovich, Lundquist, 2016; Neffke et al., 2018]. This is due to the high aggregation of macrodata, which leads to the loss of significant research results. 
We used the Perm region as an object of analysis. The choice of this region was not accidental. First, the Perm region is in fourth place after Moscow, St. Petersburg, and the Moscow region in the absolute value of budget expenditures on ICT for $2019^{4}$. Moreover, according to forecasts of the Perm region government, "the region plans to enter the top 10 regions with a developed IT sector and raise the share of the digital component of its economy up to $4 \%$ by 2024" [Makhonin, 2020]. This means that digitalization is an obvious priority of the region, which affects the demand for labor. Second, the Perm region plays a crucial role in the integration of the structure of Russia's socio-economic space. It is located on the border between the industrially developed European part of Russia and the predominantly raw eastern zone of the country. Acting as a transitional link from the industrial-agricultural Volga region to the old industrial metallurgical and machinebuilding Urals [Sharygin, 2014, p. 27], the Perm region unites municipalities that are different in their industry specifics, which is crucial for this study. The diversity of industry specifics determines the development of various professions in the territory of the region, which in turn improves the quality of the study in the field of labor market transformation.

An analysis of demand in the regional labor market in the context of specific profiles of specialists was carried out on the example of the Perm region. As the informational basis of the study, we used data from information-analytical databases of the Federal State Statistics Service of the Russian Federation (Rosstat) ${ }^{5}$, the Perm region open data portal, as well as data from the official site of the Perm region population employment center ${ }^{6}$. All calculations were made according to the statistics derived for 2017 for 47 municipalities of the Perm region. The choice of 2017 is stipulated by the availability of the most recent data for all municipalities of the Perm region at the time of carrying out the research.

To assess the presence of spatial clustering of municipalities by registered unemployment rate, this study used the tools of spatial econometrics, in particular, the global Moran index (global spatial autocorrelation) was calculated. It allows to determine not only the presence of spatial heterogeneity in the distribution of the studied indicator, but also the centers of localization and concentration of resources ("growth poles") and territories affected by spillover effects.

The global Moran index is calculated using the following formula:

$$
I=\frac{\sum_{i} \sum_{j} w_{i j}\left(\text { unem }_{i}-\overline{\text { unem }}\right)\left(\text { unem }_{j}-\overline{\text { unem }}\right)}{\frac{1}{n} \sum_{i}\left(\text { unem }_{i}-\overline{\text { unem }}\right)^{2} \sum_{i} \sum_{j} w_{i j}},
$$

where $w_{i j}$ - weight matrix element $W$;

unem $_{i}$ - registered unemployment rate in the municipality $i$

$\overline{\text { unem }}$ - average registered unemployment rate in the Perm region;

$n-$ total nubmer of municipalities $(n=47)$.

${ }^{4}$ CNews Analytics (2019) CNews Releases ICT Spending Regions Ranking. (2019) CNews Analytics. URL: https://cnews.ru/news/top/2019-10-23_cnews_opublikoval_rejting_regionov (accessed: 20.04.2020). (In Russian)

${ }^{5}$ Federal State Statistics Service. URL: https://rosstat.gov.ru/ (accessed: 20.04.2020). (In Russian)

${ }^{6}$ The Perm region population employment center. URL: http://cznperm.ru/ (accessed: 20.04.2020). (In Russian) 
The Moran spatial autocorrelation index is in the range from -1 to 1 . At zero value of the coefficient the spatial correlation is absent. Values from -1 to 0 indicate negative spatial correlation, i. e. neighboring municipalities are not similar to each other according to the studied indicator. For values from 0 to 1 , it can be argued that there is a positive spatial correlation, i.e. on the contrary, neighboring municipalities are similar to each other in the studied parameter and form clusters.

Boundary weight matrix $W$ was used in the process of research, its elements $\left(w_{i j}\right)$ are equal to:

$$
w_{i j}=\left\{\begin{array}{c}
0, \text { ifmunicipalitiesi } \wedge \text { jdonothavecommonborders } \\
1, \text { ifmunicipalitiesi } \wedge \text { jhavecommonborders }
\end{array} .\right.
$$

The boundary matrix $W$ was created by the authors according to information given at the Perm region open data portal. A local Moran index was also calculated for each municipality $I_{L i}$ using the following formula:

$$
I_{L i}=n \times \frac{\left(\text { unem }_{i}-\overline{\text { unem }}\right) \sum_{j=1}^{n} w_{i j}\left(\text { unem }_{j}-\overline{\text { unem }}\right)}{\sum_{i=1}^{n}\left(\text { unem }_{i}-\overline{\text { unem }}\right)^{2}},
$$

The local Moran index shows whether a given municipality differs from other territories or not. If the index value is positive, there is a positive spatial correlation, i. e. according to the studied parameter, this municipality is similar to its neighbors. A negative value of the local autocorrelation index, on the contrary, means that the municipality under consideration differs significantly from neighboring territories. The larger the modulus of the index value, the more this municipality is similar to or different from its neighbors (in the case of a negative index value).

To analyze demand in the Perm region labor market in the context of specialist profiles, the coefficients of localization of the required specialists of the $i$-th profile in the $r$-th municipality were calculated $\left(L Q_{i r}\right)$ using the following formula:

$$
L Q_{i r}=\frac{q_{i r}}{Q_{r}} \div \frac{q_{i}}{Q},
$$

where $q_{i r}$ is the number of specialists of the $i$-th profile required in the municipality $r$;

$q_{i}$ is the total number of specialists of the $i$-th profile required in the Perm region;

$Q_{r}$ is the total number of specialists required in the municipality $r$;

$Q$ is the total number of specialists required in the Perm region.

The value of the localization coefficient shows the level of concentration of demand for specialists of the same profile on the territory of the municipality. Then, if the localization coefficient is greater than 1 , it means a high demand for specialists of a certain profile in a certain municipality, compared to the situation in the region as a whole. The higher the localization coefficient is, the higher the demand for specialists of this profile in a given municipality in comparison with the demand in the whole region can be observed.

In addition to the tools of economic statistics and spatial econometrics, the study used methods of cartographic data visualization. 


\section{Results}

Global and local Moran's indices were calculated in statistical software package Stata 13 based on statistical data on the registered unemployment rate $^{7}$ in the municipalities of the Perm region for $2017^{8}$. The boundary matrix was used as the weight matrix. The authors revealed a positive spatial autocorrelation among neighboring municipalities, i. e. there is a clustering of municipalities by the proportion of unemployed citizens. Table 1 presents the results of calculating the Moran index and its test statistics.

Table 1. Moran index for the indicator "The registered unemployment rate, calculated on the basis of the number of unemployed citizens by the municipalities of the Perm region," 2017 (weight matrix - boundary matrix)

\begin{tabular}{|c|c|c|c|c|}
\hline Moran index & $\mathrm{E}(\mathrm{I})$ & $\mathrm{Sd}(\mathrm{I})$ & z-statistics & p-value \\
\hline 0.285 & -0.022 & 0.095 & 3.208 & 0.001 \\
\hline
\end{tabular}

S o u r c e: authors' calculations based on the data given at: Open Data Portal (2020).

The calculated spatial autocorrelation index showed that the registered unemployment rate is characterized by spatial heterogeneity. As a rule, municipalities of the first level (cities) are characterized by relatively low rates of registered unemployment. According to the results of spatial autocorrelation analysis, these municipalities include the following ones: Berezniki, Kudymkar, Kungur, Perm and Solikamsk, located in the Low Low (LL) quadrant of the Moran scatter plot (Fig. 1) $)^{9}$. Developed infrastructure, high production potential, favorable social conditions for self-realization attract labor resources, ensuring a high level of employment in the relevant territory.

On the contrary, municipalities with high rates of registered unemployment do not have sufficient resources and conditions for the employment and self-realization of trained personnel. As a rule, these are rural settlements, which, according to spatial autocorrelation analysis, include: Gaynsky, Kosinsky, Kochevsky, Krasnovishersky, Chastinsky, Cherdynsky, Yurlinsky municipal districts.

The Moran scatter plot allows to see distribution of municipalities into four groups: High - High $(\mathrm{HH})$ - municipalities with high rates of registered unemployment, surrounded by similar municipalities $(\mathrm{z}>0, \mathrm{Wz}>0)$; High - Low - municipalities with high rates of registered unemployment, surrounded by municipalities with lower rates of registered unemployment $(\mathrm{z}>0, \mathrm{Wz}<0)$; Low — High — municipalities with low rates of registered unemployment, but surrounded by municipalities with higher rates $(z<0$, $\mathrm{Wz}>0$ ); LL are the most economically sustainable municipalities with low rates of registered unemployment, surrounded by similar municipalities $(\mathrm{z}<0, \mathrm{Wz}<0)$.

${ }^{7}$ The choice of the indicator for registered unemployment is due to the availability of open data in the official statistical collections of the Perm region. The measurement of the overall unemployment rate by municipalities is not carried out by the regional statistics authorities of the Perm region.

${ }^{8}$ Statistical yearbook of the Perm region. (2018). Statistical collection, Territorial agency of the Federal State Statistics Service for the Perm Territory (Permstat). Perm, p. 66 (In Russian); Open Data Portal (2020). Open region. Perm Krai. URL: http://opendata.permkrai.ru/opendata/Default.aspx (accessed: 15.04.2020). (In Russian)

${ }_{9}^{9}$ In total, there are 12 municipalities in the LL quadrant, in addition to the listed ones they are Dobriansky, Krasnokamsky, Kuedinsky, Lysvensky, Osinsky, Permsky, Tchaikovsky, Chusovsky. 


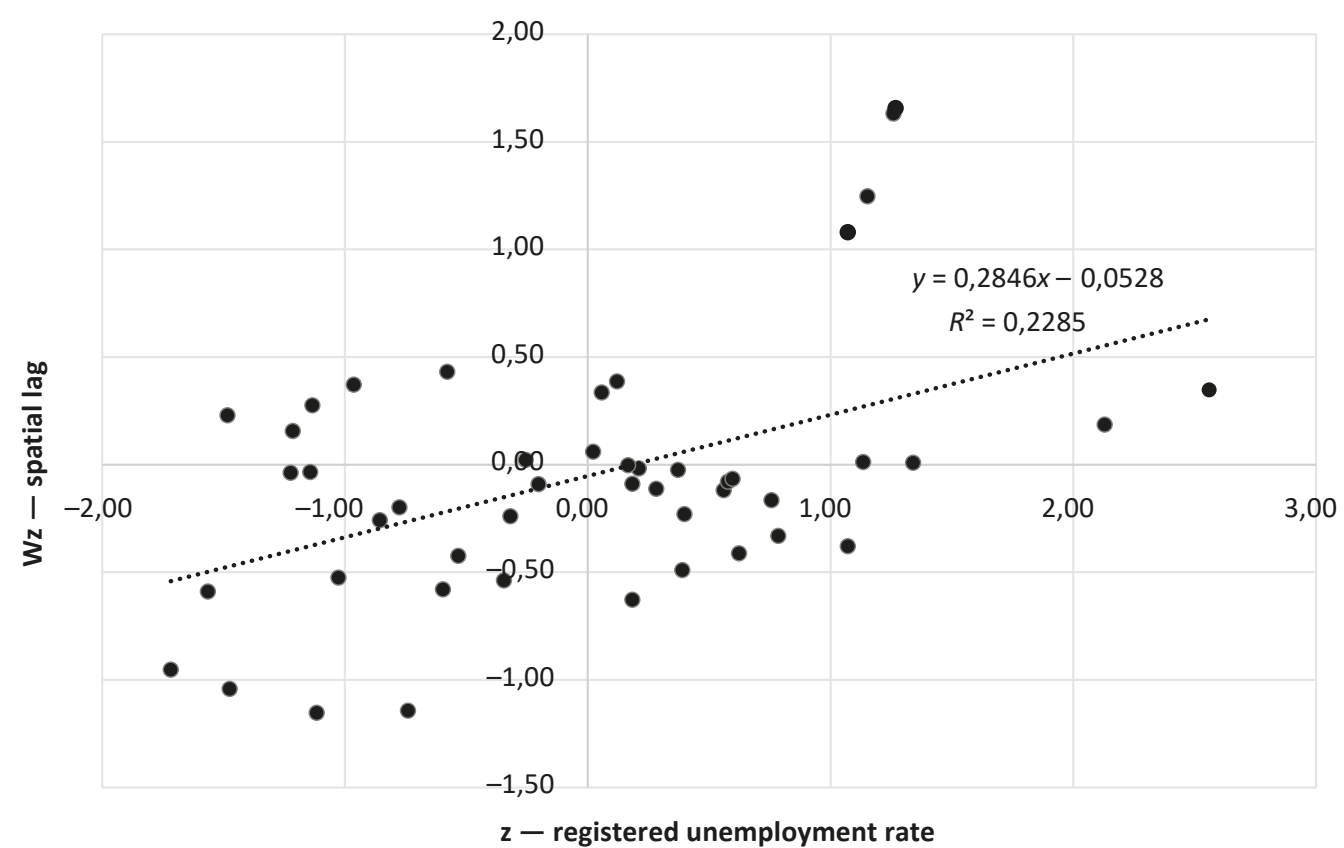

Fig. 1. Moran scatter plot by registered unemployment rate, 2017

Table 2 shows the list of municipalities that have the highest values of the local Moran index among the territories included in the $\mathrm{HH}$ and LL groups.

As it can be seen from the table, the highest value of the local Moran index is in the $\mathrm{HH}$ group of the Gaynsky municipal district, i. e. this municipality is most similar to its neighbors (all neighbors have a high rate of registered unemployment). In the LL group,

Table 2. List of municipalities with the highest calculated local Moran's indices in the High - High and Low - Low groups, 2017

\begin{tabular}{|l|c|c|c|c|c|}
\hline \multicolumn{7}{|c|}{ Municipality } & Ii & E(Ii) & sd(Ii) & z & p-value \\
\hline \multicolumn{7}{|c|}{ High - High group } \\
\hline Gaynsky municipal district & 2.147 & -0.022 & 0.555 & 3.908 & 0 \\
\hline Kochevsky municipal district & 2.101 & -0.022 & 0.555 & 3.825 & 0 \\
\hline Cherdynsky municipal district & 1.469 & -0.022 & 0.475 & 3.137 & 0.001 \\
\hline Yurlinsky municipal district & 1.182 & -0.022 & 0.555 & 2.169 & 0.015 \\
\hline Kosinsky municipal district & 0.908 & -0.022 & 0.347 & 2.684 & 0.004 \\
\hline \multicolumn{7}{|l|}{ Low - Low group } \\
\hline The city of Berezniki & 1.67 & -0.022 & 0.555 & 3.049 & 0.001 \\
\hline The city of Perm & 1.57 & -0.022 & 0.555 & 2.868 & 0.002 \\
\hline The city of Solikamsk & 1.314 & -0.022 & 0.555 & 2.408 & 0.008 \\
\hline Perm municipal district & 0.941 & -0.022 & 0.32 & 3.006 & 0.001 \\
\hline The cityof Kungur & 0.864 & -0.022 & 0.982 & 0.902 & 0.184 \\
\hline
\end{tabular}

S o u r c e: authors' calculations based on the data given at: Open Data Portal (2020). 


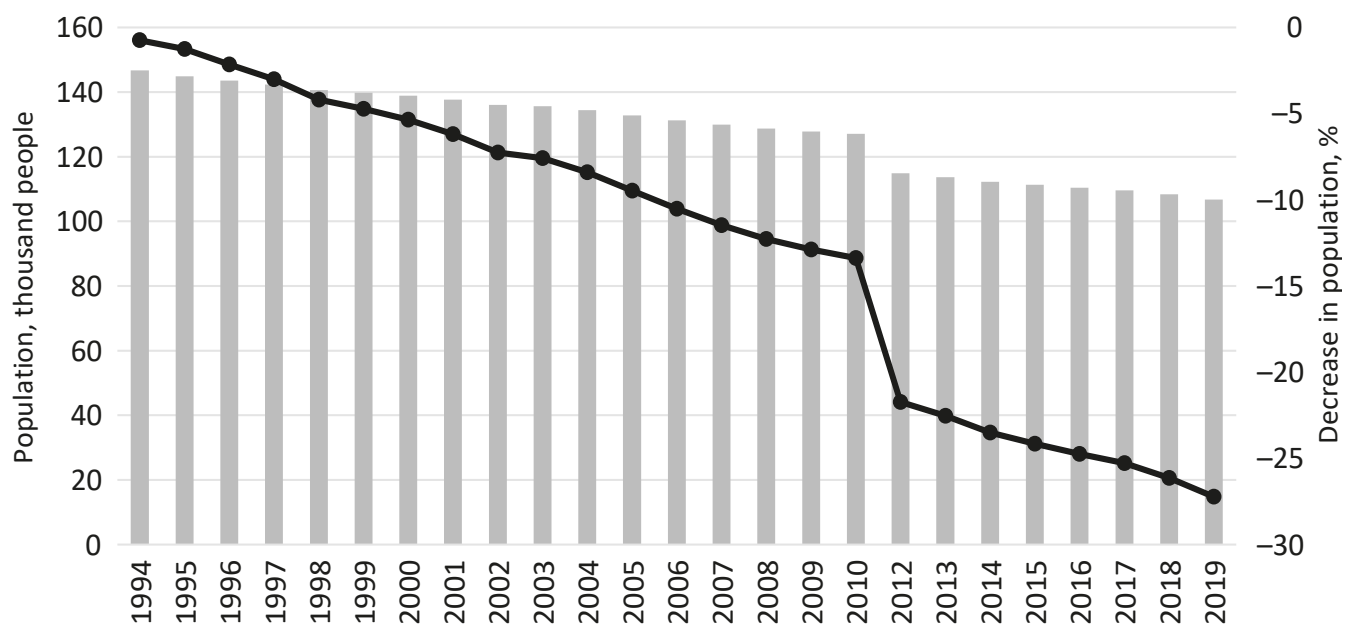

Population, thousand people -Decrease in population, $\%$ of the population of the previous period

Fig. 2. The dynamics of the population in the Komi-Perm district in 1994-2019

S o u r c e: constructed by the authors based on data given at Statistical yearbook of the Perm region: Statistical yearbook of the Perm region (2019). Statistical collection, Territorial agency of the Federal State Statistics Service for the Perm Territory (Permstat). Perm, p. 30. (In Russian)

the highest value of the local Moran index is observed in Berezniki (i. e., the neighbors of Berezniki have a low rate of registered unemployment).

The municipalities of the HH-group are supposed to be a priority for Perm's regional authorities. They form a cluster of territories with high rate of registered unemployment and are part of a single Komi-Perm district. The Komi-Perm district was an autonomous region of the Russian Federation until 2005. After joining the Perm region, the KomiPerm district received the status of an administrative-territorial unit with a special status. The administrative center is the city of Kudymkar. In addition to it, the district includes the following municipal areas: Gaynsky, Kosinsky, Kochevsky, Kudymkarsky, Yurlinsky, Yusvinsky.

There are large deposits of oil, iron, brown coal and peat on the territory of the Komi-Perm district. But the main wealth of the territory is the presence of extensive forest resources (occupy over $75 \%$ of the district). Thus, the leading sectors of the economy in 2018 according to the indicator "Structure of organizations turnover by type of economic activities" are: forestry, woodworking industry and agriculture (Kochevsky $-51.3 \%$, Kudymkarsky $-52.4 \%$ ), mining (Yusvensky $-84.7 \%$ ), trade and repair of vehicles (Kudymkar - 44.5\%, Gaynsky - 34.2\%, Yurlinsky - 60.3\%), as well as activities in the field of health and social services (Kosinsky $-56 \%)^{10}$.

Despite Komi-Perm's rich natural resources, the population has been declining since 1994 (Fig. 2).

It can be seen from the above graph, that the population of the district has been decreasing over the last 25 years, and has decreased by 39,955 people $(-27.23 \%)$. The main

\footnotetext{
${ }^{10}$ Statistical yearbook of the Perm region. (2019). Statistical collection, Territorial agency of the Federal State Statistics Service for the Perm Territory (Permstat). Perm, 357 p. (In Russian)
} 
reason for the population decline is migration. Thus, according to statistics, the migration loss of the population was approximately 1,100 people per year in the Komi-Perm Autonomous disrict over the past 7 years, while the natural loss was 48 people per year ${ }^{11}$. It should also be noted that the official figures may not reflect the real picture, as some people have a residence permit in the villages, but have long left for other regions. The current situation is a consequence of high rate of registered unemployment in the municipalities of the Komi-Perm district ${ }^{12}$.

Four out of seven municipalities of the Komi-Perm district were included in the $\mathrm{HH}$ group (Gaynsky, Kosinsky, Kochevsky, Yurlinsky municipal districts) according to the results of the analysis. Note that the leading place in the structure of the economies of these municipal regions is occupied by the forest industry (logging and wood processing). At the same time, the development of the estimated cutting area amounted to an average of $50 \%$ from the annual development target ${ }^{13}$, which indicates problems both in the main branch of the municipality and in the level of diversification of the economy as a whole.

Further, on the basis of open data from the list of specialties for which professional and additional professional training of unemployed citizens in municipalities of the Perm region were carried out in $2020^{14}$, we calculated the localization coefficients of the required specialists for the $i$-th profile in the $r$-th municipality $\left(L Q_{i r}\right)$. It should be noted that this list is compiled annually by the Employment Center for the Perm Region on the basis of applications from territorial divisions.

The territorial divisions when drawing up training plans, are guided by employers' requests to state employment agencies. Preliminarily, we processed a data file to calculate the localization coefficient. First, we calculated the number of places allocated for training in a particular specialty in each municipality. Second, all training programs were divided into 6 groups in terms of their classification by specialty profiles: 1. Information technology; 2. Beauty and design; 3. Construction and architecture; 4. Logistics; 5. Economics, business; 6 . Service sector (Table 3). And third, the total number of places for training for each specialty profile for each municipality was calculated.

Since the employment center, when drawing up plans for training in certain specialties, focuses on demand from employers, then the calculations revealed the real demand of municipalities for various profiles of specialists.

The interpretation of the results showed the most interesting municipalities from the $\mathrm{HH}$ and LL groups, since according to the results obtained, it is precisely in these groups that one can test the hypothesis on the significance of spatial effects in the demand for labor in the context of digitalization. The choice of municipalities from the HH and LL groups is due to the fact that these groups include municipalities with relatively similar (high or low) values of the studied attribute. On the contrary, in the High - Low and Low - High groups there are municipalities, which differ significantly from their neighbors in terms of the studied trait.

${ }^{11}$ Statistical yearbook of the Perm region. (2019). Statistical collection, Territorial agency of the Federal State Statistics Service for the Perm Territory (Permstat). Perm, p. 32, 39 (In Russian)

${ }^{12}$ Statistical yearbook of the Perm region. (2019). Statistical collection, Territorial agency of the Federal State Statistics Service for the Perm Territory (Permstat). Perm, p. 44 (In Russian)

${ }^{13}$ Kochevsky municipal district. (2020). Head of Region Reports. URL: http://admkochevo.ru/Organyvlasti/glava_kochevskogo_municipalnogo_rajona/otchety_glav/ (accessed: 11.04.2020) (In Russian).

${ }^{14}$ The list of specialties for which retraining will be carried out in 2020. (2020) Employment Center of the Perm Region. URL: https://clc.to/czpermdata (accessed: 11.11.2020). (In Russian) 
Table 3. Distribution of professions by major specialty profiles

\begin{tabular}{|c|c|}
\hline Specialty profile & Professions \\
\hline 1. Information technology & $\begin{array}{l}\text { 1C: Enterprise 8; Internet Marketing; Computer graphics; Software } \\
\text { controlled machine operator; The operator of electronic computers and } \\
\text { computers; Controller of electronic equipment and instruments }\end{array}$ \\
\hline 2. Beauty and design & $\begin{array}{l}\text { Visagiste; Interior Designer; Cutter; Designer of art products; Landscape } \\
\text { designer; Tailor; Manicure specialist; Pedicure specialist; Florist }\end{array}$ \\
\hline $\begin{array}{l}\text { 3. Construction and } \\
\text { architecture }\end{array}$ & $\begin{array}{l}\text { Mason; Hot metal spreader; Shielded gas arc welder; Slinger; Management } \\
\text { of operation and maintenance of an apartment building; Examination and } \\
\text { development of design estimates in construction }\end{array}$ \\
\hline 4. Logistics & $\begin{array}{l}\text { Loader driver; Storekeeper; Motorist (driver); Operations in warehouse } \\
\text { logistics and transport logistics; Tractor driver }\end{array}$ \\
\hline 5. Economics, business & $\begin{array}{l}\text { Archivist; Accountant; Personnel Inspector; contractor in the field of } \\
\text { procurement of goods, works, services to ensure state and municipal needs } \\
\text { under } 44 \text { Federal law; Trade manager; Organization of commercial activity; } \\
\text { Organization of small and medium-sized businesses }\end{array}$ \\
\hline 6. Service sector & $\begin{array}{l}\text { Organization of management and operation of real estate in multi- } \\
\text { apartment buildings; Fundamentals of Entrepreneurship; Administrative } \\
\text { Secretary; HR Specialist; Occupational health and safety specialist; } \\
\text { Management of state and municipality procurement under 44 Federal law; } \\
\text { HR management and HR administration } \\
\text { Bartender; Preschool pedagogy and psychology; Confectioner; Cashier; } \\
\text { Laboratory Assistant for Chemical Analysis; Lifter; Babysitter; Gas station } \\
\text { operator; Boiler operator; Oil and gas operator; Security guard; Hairdresser; } \\
\text { Baker; Cook; Assistant Driller Overhaul; Seller; Beekeeper; Gardener; } \\
\text { Nurse; Car fitter; The fitter for the repair and operation of gas equipment; } \\
\text { Repairman; Plumber; Photographer; Flower girl; Fire and security alarm } \\
\text { electrician; Electrician for repair and maintenance of electrical equipment }\end{array}$ \\
\hline
\end{tabular}

S o u r c e: systematized by the authors based on data Employment Center of the Perm Region: The list of specialties for which retraining will be carried out in 2020 (2020).

So, if the hypothesis is true, then in the municipalities from the $\mathrm{HH}$ group the localization coefficient of the required specialists in the group of the specialty "Information Technologies" should be more than one and the maximum among other groups. On the contrary, in municipalities from the LL group, the distribution of the localization coefficients of the required specialists of different specialties should be uniform (the values of the localization coefficients are approximately equal for all profiles). The results of calculations of the demand localization coefficient for specialists of different profiles in the municipalities of the LL group (municipalities with low rate of registered unemployment, surrounded by the same territories) are presented in Table 4.

According to Table 4, the distribution of localization coefficients of the demanded specialists in the municipalities of the LL group (municipalities with low rate of registered unemployment, surrounded by the same territories) is not expressed in favor of certain individual groups of professions.

Fig. 3 shows a cartographic visualization of the analysis results for spatial heterogeneity of unemployment indicators (Fig. 3a) and the results of calculating the localization coefficient for specialists demand of different profiles (Fig. 3b). At the same time, in Fig. 3b, the municipality is painted over with the color of that profile that has maximum value for its localization coefficient. 
Table 4. Localization factors for specialists demand of different profiles in the municipalities from the Low - Low and High - High group

\begin{tabular}{|c|c|c|c|c|c|c|}
\hline Municipality & $\begin{array}{c}\text { Information } \\
\text { technology }\end{array}$ & $\begin{array}{l}\text { Beauty and } \\
\text { design }\end{array}$ & $\begin{array}{l}\text { Construction } \\
\text { and } \\
\text { architecture }\end{array}$ & Logistics & $\begin{array}{l}\text { Economics, } \\
\text { business }\end{array}$ & $\begin{array}{l}\text { Service } \\
\text { sector }\end{array}$ \\
\hline \multicolumn{7}{|c|}{ Low - Low group } \\
\hline Berezniki city & 1.093 & 0.222 & 0.166 & 1.465 & 3.203 & 0.917 \\
\hline Kudymkar city & 0.925 & 0.998 & 1.495 & 0.732 & 0.000 & 1.167 \\
\hline Kungur city & 1.703 & 0.891 & 0.534 & 0.754 & 0.999 & 0.844 \\
\hline Solikamsk city & 0.376 & 0.794 & 1.189 & 2.359 & 1.563 & 1.025 \\
\hline Dobryansky & 1.158 & 2.810 & 0.458 & 0.646 & 1.069 & 0.413 \\
\hline Krasnokamsky & 0.167 & 0.440 & 0.000 & 0.000 & 4.620 & 1.240 \\
\hline Kuedinsky & 0.848 & 1.006 & 1.340 & 2.363 & 0.000 & 1.009 \\
\hline Lysvensky & 2.012 & 0.717 & 0.000 & 0.000 & 0.000 & 1.213 \\
\hline Osinsky & 0.656 & 1.730 & 1.296 & 1.429 & 0.000 & 0.975 \\
\hline Perm & 1.099 & 0.949 & 0.599 & 1.056 & 3.238 & 0.582 \\
\hline Chaikovsky & 0.941 & 0.914 & 0.881 & 0.690 & 2.459 & 0.822 \\
\hline Chusovskoy & 1.038 & 1.742 & 3.729 & 1.315 & 0.000 & 0.187 \\
\hline \multicolumn{7}{|c|}{ High - High group } \\
\hline Bolshesosnovsky & 0.000 & 2.199 & 3.294 & 0.000 & 0.000 & 0.826 \\
\hline Gainsky & 1.100 & 1.055 & 0.988 & 2.440 & 0.462 & 0.843 \\
\hline Gornozavodsky & 1.751 & 0.660 & 0.329 & 0.000 & 0.963 & 1.074 \\
\hline Kizel city & 0.944 & 1.120 & 1.865 & 0.000 & 0.436 & 1.029 \\
\hline Kosinsky & 1.601 & 0.264 & 0.791 & 0.000 & 0.000 & 1.388 \\
\hline Kochevsky & 1.852 & 0.244 & 1.098 & 1.937 & 0.000 & 0.918 \\
\hline Krasnovishersky & 0.625 & 1.649 & 1.235 & 0.000 & 1.444 & 0.930 \\
\hline Suksunsky & 1.633 & 1.346 & 0.000 & 2.846 & 0.000 & 0.759 \\
\hline Chastinsky & 0.000 & 0.440 & 2.636 & 0.000 & 0.000 & 1.653 \\
\hline Cherdynsky & 2.858 & 0.188 & 0.565 & 0.000 & 0.330 & 0.779 \\
\hline Yurlinsky & 1.286 & 0.377 & 2.824 & 0.996 & 0.000 & 0.850 \\
\hline
\end{tabular}

So u r ce: calculated by the authors based on the data given by Employment Center of the Perm region: The list of specialties for which retraining will be carried out in 2020 (2020).

As it can be seen from Fig. 3, the municipalities with the lowest rates of registered unemployment are located mainly in the central part of the Perm region (LL group), surrounded by similar regions, while the regions with the highest rates of registered unemployment are on the periphery of the subject (HH group). These conclusions are consistent with the results obtained in the work by D. Puga. By examining regional alignment policies in European countries, implemented in the last two decades, D. Puga concludes that "the unemployment outcomes of individual regions are much closer to the outcomes of neighbouring regions (domestic and foreign) than to the average outcomes of other regions within the same Member State" [Puga, 2002, p. 9]. 

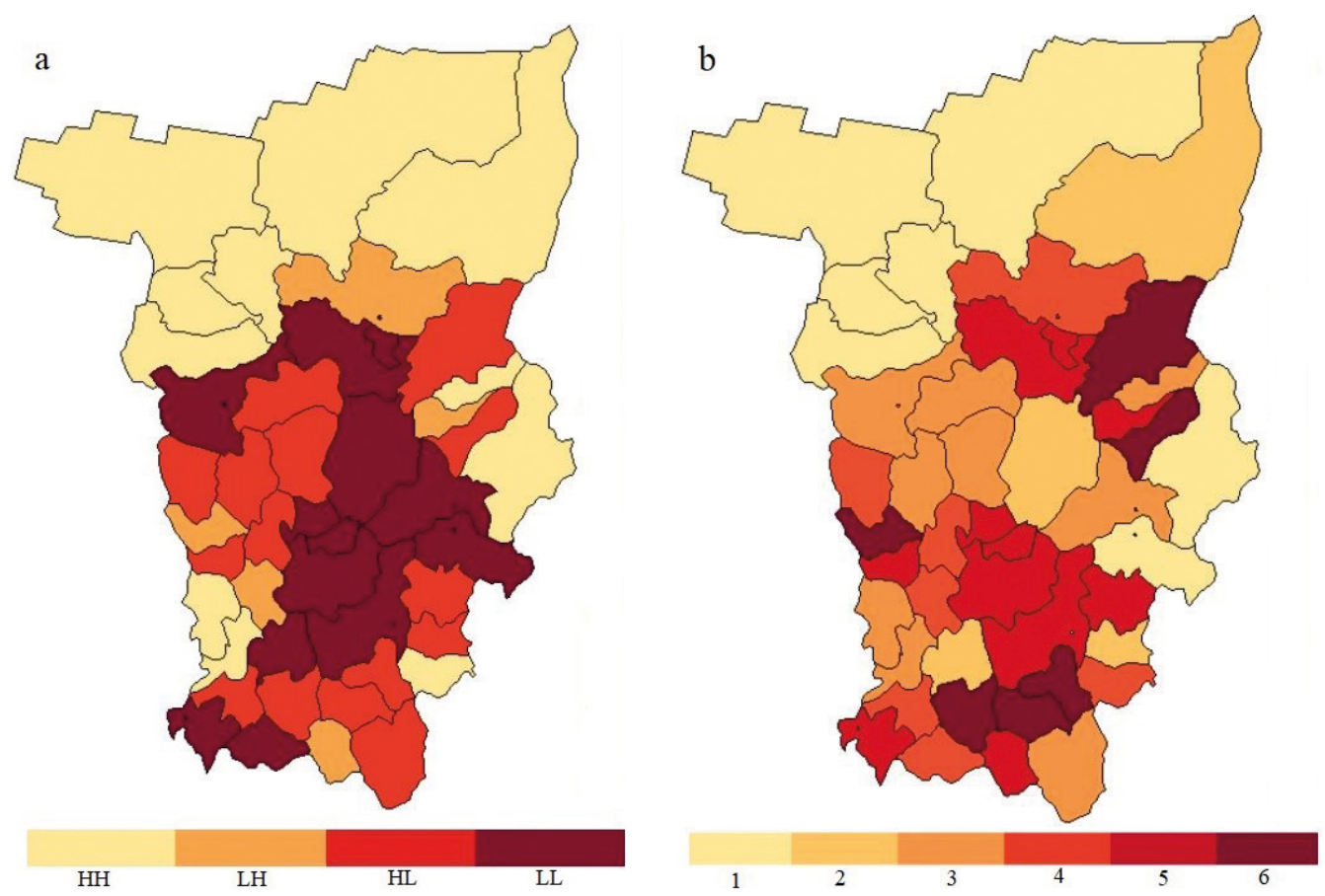

Fig. 3. Cartographic visualization of (a) the analysis results for spatial heterogeneity of unemployment indicators: HH - High - High group; LH — Low - High group; HL — High - Low group; LL - Low Low group and (b) the results of calculating the localization coefficient for specialists demand of different profiles: 1 - IT; 2 - Beauty and Design; 3 - Construction and architecture; 4 - Logistics; 5 - Economics, business; 6 - Services sector.

In addition, according to our results, in most municipalities from the $\mathrm{HH}$ group (municipalities with a high rates of registered unemployment surrounded by the same municipalities), the localization coefficient of the required specialists in the group of the specialty "Information Technologies" is the highest among other groups. In most municipalities from the LL group, the distribution of the localization coefficients of the required specialists is uniform, i. e. that the value of the localization coefficient in several profiles at once is either more than one or less than one. So, for example, most of the municipalities of the LL group have a localization coefficient exceeding 1 in more than three profiles. This indicates the absence of a clearly expressed demand for specialists in a specific profile.

It should be noted that the results obtained can be extrapolated to the following periods of time, since, first, the analysis of the available statistics of the level of registered unemployment for the municipalities of the Perm Territory showed a low range of its variation over 7 years ${ }^{15}$, second, in Russia there is a low level of interregional and intersectoral mobility [Vakulenko, 2020, p. 1204].

${ }^{15}$ Municipalities of the Perm Territory. (2019) Statistical collection. Territorial body of the Federal State Statistics Service for the Perm Territory (Permstat). Perm, p. 44. (In Russian) 


\section{Conclusions}

Regulation of employment is a key issue of economic theory and an important problem of state and municipal government. In this paper, an attempt was made to assess the impact of the digital transformation of the economy on the demand for labor based on the tools of spatial econometrics. The most important findings of the study include the following ones:

1. Despite the polarity of views on the prospects for changing the demand for labor under the influence of digitalization, scholars agree on the need to modernize and adapt the system of training and education.

2. Spatial inter-territorial relations have a significant impact on the demand for labor, which makes it necessary to take into account spatial effects when modeling the dynamics of population employment indicators. The calculations showed that the cluster of municipalities with the lowest rates of registered unemployment is located in the central part of the analyzed region, while the cluster of territories with the highest rates of registered unemployment rate is located on its periphery.

3. Differences in the levels of development of municipalities lead to spatial heterogeneity in the distribution of unemployment in the region. This causes the occurrence of both centers of concentration of labor resources ("growth poles"), and donor territories. This, in turn, necessitates taking into account spillover effects when developing programs to support employment.

4. An empirical test of the hypothesis formulated in the study, about the importance of spatial effects in the demand for labor in the context of digitalization, is proen to be validi. In municipalities with a high rates of registered unemployment, the localization coefficient of the required specialists in the "Information Technologies" group is not only stably greater than one, but is the highest among other groups of professions. These results may be a direct result of the lack of competent specialists in the field of information and communication technologies in peripheral regions, which, along with migration processes, leads to high unemployment. Whereas in municipalities with low rates of registered unemployment, the distribution of the localization coefficients of the required specialists is uniform and not expressed in the direction of individual groups of professions.

5. A set of measures of national and municipal policies aimed at curbing the outflow of labor, especially young people from peripheral depressed territories, is needed. The calculation of the localization coefficients of the required specialists within the framework of the analysis of demand on the labor market in the Perm region has proved that employment policy should be based on measures to formation of professional development programs in the field of digital technologies.

6. Spatial effects are potentially a strong driver for the development of regional labor markets. Therefore, one of the main tools of the municipal policy in the field of strategic planning should be the consideration of the influence of spatial factors on the economic development of the territory.

Taking into account the results obtained during the analysis of the authors, the following directions for further study of the problem can be formulated. One of them may be the adaptation of specialized state programs of digitalization and retraining of the population in depressed municipalities based on the so-called individual approach. The next direction seen by us is a cross-analysis of the relationship between performance indicators 
and digitalization of jobs. Solving the issue of increasing high-performance jobs in the light of global digitalization can become a significant factor in the growth of the domestic economy and undoubtedly requires increased attention. As the third area of further research, let us designate a foresight study of the qualitative characteristics of the category of "smart" workers, generating added knowledge and skill chains. The definition "skill chains" is a new area of research [Barzotto, Propris, 2018], but hopes for increasing productivity are associated with it. Taken into account the high sensitivity of labor productivity to the level of employment [Rusanovsky, Markov, 2018; Domnich, 2015], we believe that the study of the development of skill chains will be a good continuation of this study.

\section{References}

Annunziata M., Biller S. (2014) The Future of Work. General Electric Discussion Paper. URL: http://files. gecompany.com/gereports/image/FutureOfWork_8am.pdf (accessed: 02.06.2020).

Anselin L. (2006) Spatial Econometrics in Mills T. C., Patterson K. (eds) Palgrave Handbook of Econometrics. Vol. 1: Econometric Theory. Basingstoke, Palgrave Macmillan, pp.901-969.

Barzotto M., Propris L. D. (2018) Skill up: smart work, occupational mix and regional productivity. Journal of Economic Geography, iss. 19, pp. 1049-1075.

Belyaev G. Yu. (2017) Potentially negative trends in the development of modern education and their impact on education as a social phenomenon. Science today: problems and development prospects, iss. 11, pp. 52-57. (In Russian)

Bodrunov S. D., Demidenko D. S., Plotnikov V.A. (2018) Reindustrialization and the establishment of the "digital economy": harmonization of trends through the process of innovative development. Management Consulting, iss. 2, pp. 110-122. (In Russian)

Brynjolfsson E., McAfee A. (2014) The Second Machine Age: Work, Progress, and Prosperity in a Time of Brilliant Technologies. New York, Norton. $281 \mathrm{p}$.

Calvino F., Criscuolo C. (2019) Business dynamics and digitalization. OECD science, technology and industry policy papers, iss. 62.59 p. URL: https://www.oecd-ilibrary.org/docserver/6e0b011a-en.pdf?expires= 1611436553\&id $=$ id\&accname $=$ guest $\&$ checksum $=$ FFEE3AA5E3AD53259BA4AA49D0669D3C $\quad$ (ac cessed: 10.01.2021).

Demidova O.A. (2014) Spatial-autoregressive model for two groups of interconnected regions (on the example of the eastern and western parts of Russia). Applied Econometrics, vol. 2, iss. 34, pp. 19-35. (In Russian)

Diodato D., Weterings A. B. (2015) The resilience of regional labour markets to economic shocks: exploring the role of interactions among firms and workers. Journal of Economic Geography, iss. 15, pp. 723-742.

Domnich E. L. (2015) A trade-off between employment and labor productivity in Russia and OECD countries. National interests: priorities and security, iss.44, pp.38-52. (In Russian)

Elhorst J. P. (2009) "Spatial Panel Data Models" in Fischer M. M., Getis A. (eds) Handbook of Applied Spatial Analysis. Berlin, Springer, pp. 377-407.

Evangelista R., Guerrieri P., Meliciani V. (2014) The economic impact of digital technologies in Europe. Economics of Innovation and New Technology, vol. 23, iss. 8, pp. 802-824.

Frey C., Osborne M. (2013) The Future of Employment: How Susceptible are Jobs to Computerisation? Oxford Martin School (OMS) working paper. Oxford. 72 p.

Hirsch-Kreinsen H. (2016) Digitization of industrial work: development paths and prospects. Journal for Labour Market Research, iss. 49, pp. 1-14. https://doi.org/10.1007/s12651-016-0200-6

Huws U. (2014) Labor in the global digital economy: The cybertariat comes of age. New York, Monthly Review Press. 208 p.

Ivanov V. G., Kaybiyaynen A. A., Miftakhutdinova L. T. (2017) Engineering Education in the Digital World. Higher Education in Russia, iss. 11, pp. 21-29. (In Russian)

Keynes J.M. (1931) Essays in Persuasion, Chapter 2 "Economic possibilities for our grandchildren". URL: https://gutenberg.ca/ebooks/keynes-essaysinpersuasion/keynes-essaysinpersuasion-00-h.html (accessed: 28.12.2020).

Kozonogova E. V., Dubrovskaya Yu. V.,Tiunov D. A. (2020) Features of labor market changes in the conditions of economy digitalization. International Relations 2019: Current issues of world economy and poli- 
tics. Proceedings of scientific works from $20^{\text {th }}$ International Scientific Conference. $28^{\text {th }}-29^{\text {th }}$ November 2019, Smolenice Castle. Publishing Econom, pp. 600-607.

Kuznetsov N. V. (2018) Change of the employment structure and professional and qualification requirements in the era of digitalization of the economy. Modern problems of science and education, no.5. URL: http://science-education.ru/ru/article/view?id=27992 (accessed: 10.04.2020).

Lee L., Yu J. (2010) Estimation of Spatial Autoregressive Panel Data Models with Fixed Effects. Journal of Econometrics, pp. 165-185.

Lola I. S., Bakeev M. B. (2019) Digital Transformation in the Manufacturing Industries of Russia: an Analysis of the Business Tendencies Observations Results. St Petersburg University Journal of Economic Studies, vol. 35, iss. 4, pp. 628-657. https://doi.org/10.21638/spbu05.2019.407 (In Russian)

Lopez-Bazo E., Barrio T. Artis M. (2002) The regional distribution of Spanish unemployment: a spatial analysis. Regional science, iss. 81, pp. 366-389.

Lottmann F. (2012) Explaining regional unemployment differences in Germany: a spatial panel data analysis. SFB 649 discussion paper 2012-026, 56 p.

Lugovoy O., Dashkeev V., Mazayev I., Fomchenko D., Polyakov E., Hecht A. (2007) Analysis of Economic Growth in Regions: Geographical and Institutional Aspect. SSRN Electronic Journal. https://doi. org/10.2139/ssrn.1268088. (In Russian)

Makhonin D.N. (2020) The terms of the model of innovative development of the region. Budget, iss. 11. URL: http://bujet.ru/article/412926.php (accessed: 10.02.2021). (In Russian)

Markov V.A. (2015) Information technologies and spatial models in the analysis of regional localization and globalization of unemployment. Information security of the regions, vol. 2, iss. 19, pp.21-27. (In Russian)

Martynovich M., Lundquist K.-J. (2016) Technological change and geographical reallocation of labour: on the role of leading industries. Regional Studies, iss. 50, pp. 1633-1647.

Neffke F., Hartog M., Boschma R., Henning M. (2018) Agents of structural change: the role of firms and entrepreneurs in regional diversification. Economic Geography, vol. 94, iss. 1, pp. 23-48.

Pfeiffer S., Suphan A. (2015) The Labouring Capacity Index: Living Labouring Capacity and Experience as Resources on the Road to Industry 4.0. Working Paper no. 2. University of Ho-henheim, Chair for Sociology. URL: www.sabine-pfeiffer.de/files/downloads/2015-PfeifferSuphan-EN.pdf (accessed: 03.06.2020).

Pianta M. (2005) Innovation and employment in Fagerberg J., Mowery D., Nelson R. (eds). The Oxford Handbook of Innovation. Oxford, Oxford University Press, pp. 568-598.

Puga D. (2002) European regional policy in light of recent location theories. Journal of Economic Geography, iss. 2, pp. 373-406.

Rusanovsky V.A., Markov V.A. (2016) The influence of the spatial factor on the regional differentiation of unemployment in the Russian economy. Problems of forecasting, vol. 5, iss. 158, pp. 144-157. (In Russian)

Rusanovsky V.A., Markov V.A. (2018) Employment and labor productivity in macro-regions of Russia: spatial interdependencies. Problems of forecasting, vol. 2, iss. 167, pp. 36-48. (In Russian)

Rüßmann M., Lorenz M., Gerbert P., Waldner M., Engel P., Harnisch M., Justus J. (2015) Industry 4.0 - the Future and Growth in manufacturing Industries. URL: https://www.bcg.com/publications/2015/engineered_products_project_business_industry_4_future_productivity_growth_manufacturing_industries.aspx (accessed: 06.06.2020).

Sharygin M.D. (2014) Positioning of the Perm Territory in the socio-economic space of the Russian Federation. Geographical Bulletin. Social and economic geography, iss. 4, pp. 22-28.

Shatilo Yu. E., Kopkova E. S. (2017) Employment and Unemployment in a Digital Economy. Theory. Practice. Innovations, vol. 10, iss. 22, pp.66-77. (In Russian)

Tiunov D. A., Dubrovskaya Yu. V. (2019) Systematization of the causes of unemployment: institutional aspect. Vector of science of Togliatti State University. Series: Economics and Management, vol. 1, iss. 36, pp. 49-54. (In Russian)

Vakulenko E.S. (2020) Comparative Analysis of Interregional and Intersectoral Mobility in Russia. Ekonomika regiona, vol. 16, iss.4, pp.1193-1207. https://doi.org/10.17059/ekon.reg.2020-4-13 (In Russian)

Received: 30.06 .2020

Accepted: 30.06.2021 
Authors' information:

Julia V.Dubrovskaya — PhD in Economics, Associate Professor; uliadubrov@mail.ru

Elena V.Kosonogova — PhD in Economics; elena.kozonogova@gmail.com

\title{
Влияние цифровизации на рынок труда в разрезе специальностей: пространственный анализ ${ }^{*}$
}

\author{
Ю. В. Дубровская, Е. В. Козоногова
}

Пермский национальный исследовательский политехнический университет, Российская Федерация, 614000, Пермь, Комсомольский пр., 29

Для цитирования: Dubrovskaya J.V., Kozonogova E.V. (2021) The impact of digitalization on the demand for labor in the context of working specialties: Spatial analysis. Вестник СанктПетербургского университета. Экономика. Т.37. Вып.3. С.395-412. https://doi.org/10.21638/ spbu05.2021.302

Распространение цифровых технологий, а также расширение практики дистанционной работы оказывает непосредственное влияние на трансформацию рынка труда. При этом среди ученых нет устоявшегося мнения о характере и последствиях данного влияния. Основной предпосылкой работы является сравнительно небольшое количество эмпирических исследований рынка труда с учетом фактора расположения регионов друг относительно друга. В статье исходя из расчета коэффициентов локализации спроса на специалистов разных профилей была протестирована гипотеза о значимости влияния факторов месторасположения и соседства территорий на рынок труда (в частности, спрос на труд) в условиях цифровизации экономики. В качестве основного инструментария исследования были выбраны методы пространственной эконометрики. С помощью анализа глобального и локальных индексов Морана авторами была произведена оценка пространственной неоднородности уровня безработицы по муниципальным образованиям Пермского края Российской Федерации. В ходе исследования была выявлена положительная пространственная автокорреляция среди муниципалитетов-соседей, подтверждающая высокую пространственную неоднородность уровня зарегистрированной безработицы. Также были определены центры локализации и концентрации трудовых ресурсов («полюса роста») и территории, подвергшиеся влиянию спилловер-эффектов. Было доказано, что пространственные межтерриториальные связи оказывают значительное влияние на рынок труда, что обуславливает необходимость учета пространственных эффектов при моделировании динамики показателей занятости населения. Визуализация полученных результатов была произведена с помощью картографического метода. К основным перспективным направлениям исследований цифровой трансформации рынка труда можно отнести расширение специализированных государственных программ цифровизации и переобучения населения, перекрестный анализ взаимосвязей между показателями производительности и цифровизацией рабочих мест, форсайт-исследование качественных характеристик категории «умных» работников, генерирующих цепочки добавленных знаний и навыков. Представленная авторская методика анализа рынка труда на основе оценки пространственной неоднородности уровня безработицы и расчетов коэффициентов локализации является универсальной и может быть применена к различным таксономическим единицам.

* Исследование выполнено при финансовой поддержке Российского фонда фундаментальных исследований в рамках научного проекта № 19-010-00562. 
Ключевые слова: спрос на труд, уровень зарегистрированной безработицы, индекс Морана, коэффициенты локализации, цифровая экономика, пространственная неоднородность.

Статья поступила в редакцию: 30.06.2020

Статья рекомендована в печать: 30.06 .2021

Контактная информация:

Дубровская Юлия Владимировна - канд. экон. наук, доц.; uliadubrov@mail.ru

Козоногова Елена Викторовна - канд. экон. наук; elena.kozonogova@gmail.com 